\title{
Identifikasi Bakteri Escherichia coli pada Air Minum Isi Ulang yang Diproduksi DAMIU di Kelurahan Lubuk Buaya Kota Padang
}

Rani Afrisetiawati ${ }^{1}$, Erly $^{2}$, Endrinaldi $^{3}$

\begin{abstract}
Abstrak
Air merupakan komponen penting bagi tubuh. Menurut Permenkes No.492 Tahun 2010 tentang syarat mikrobiologi air minum adalah tidak ditemukannya bakteri Coliform dan Escherichia coli dalam 100 ml air. Tujuan penelitian ini adalah mengetahui kualitas air minum yang diproduksi depot air minum isi ulang di Kelurahan Lubuk Buaya. Penelitian bersifat deskriptif dengan melakukan pemeriksaan bakteriologi sampel air di Laboratorium Mikrobiologi Fakultas Kedokteran Universitas Andalas dari Februari sampai Oktober 2014. Sampel adalah air dari masing-masing depot air minum isi ulang di Kelurahan Lubuk Buaya yang sudah dimasukkan ke dalam galon. Penelitian ini terdiri dari empat tes, yaitu tes presumtif, konfirmatif, lengkap dan identifikasi. Hasil pemeriksaan laboratorium menunjukkan empat dari dua belas sampel $(33,3 \%)$ mengandung bakteri Coliform dan satu dari empat sampel tersebut mengandung Escherichia coli. Pengawasan terhadap depot air minum isi ulang di Kelurahan Lubuk Buaya harus lebih ditingkatkan. Kader Kesehatan setempat diharapkan dapat memberikan penyuluhan kepada pemilik atau operator depot agar memperhatikan kebersihan depot serta peralatan yang digunakan.
\end{abstract}

Kata kunci: air minum isi ulang, Coliform, Escherichia coli

\begin{abstract}
Water is an essential component for the human body. According to Permenkes No. 492 Tahun 2010 about microbiological standards for drinking water is the absence of coliform and Escherichia coli in $100 \mathrm{ml}$ of water. The objective of this study was to find the quality of drinking water produced by drinking water refill depots at Lubuk Buaya Padang based on microbiological standards of drinking water. The research was conducted using by bacteriological test on 12 water samples at the Laboratory of Microbiology, Facultyof Medicine, University of Andalas from February until Oktober 2014. This research consisted four tests: the presumptive test, confirmative test, completetest and identification test. Based on the result of laboratory test, there were four samples (33,3\%) from twelve samples contain Coliform bacteria and one of them contain Escherichia coli. Controlling of drinking water refill depots at Lubuk Buaya should have been improved. The officers of Public Health at Lubuk Buaya must give an advice to the owners or depot operators about hygiene of depot and tools that they used.
\end{abstract}

Keywords: drinking water refill, Coliform, Escherichia coli

Affiliasi penulis: 1. Prodi Profesi Dokter FK UNAND (Fakultas Kedokteran Universitas Andalas Padang), 2. Bagian Mikrobiologi FK UNAND, 3. Bagian Kimia FK UNAND.

Korespondensi: Rani Afrisetiawati, Email :

rani.afrisetiawati@yahoo.com, Telp: 085263301002

\section{PENDAHULUAN}

Air merupakan kebutuhan dasar bagi kehidupan manusia yang harus dipenuhi. Kehidupan manusia tidak terlepas dari kebutuhan akan air bersih terutama air minum. Selama ini kebutuhan akan air dipenuhi 
dari berbagai sumber antara lain air tanah, air sungai, air hujan, air pegunungan dan air laut yang diolah sedemikian rupa dan ditawarkan sebagai bahan baku air. $^{1}$

Air selain bermanfaat bagi manusia juga bisa sebagai media bagi pertumbuhan bakteri. Bakteri patogen dapat menyebabkan penyakit dengan keluhan diare seperti disentri, tipus, dan kolera melalui air yang diminum. Bakteri Escherichia coli termasuk bakteri yang dapat menyebabkan keluhan diare. Tercatat 38,29\% dari seluruh kasus diare di Rumah Sakit Persahabatan Jakarta disebabkan oleh Escherichia coli. $^{2}$

Air yang aman diminum adalah air bersih yang harus memenuhi persyaratan secara fisika, kimia, radioaktif dan mikrobiologi yang telah ditetapkan oleh pemerintah. Parameter wajib penentuan kualitas air minum secara mikrobiologi adalah total bakteri Coliform dan Escherichia coli. Salah satu syarat air bersih yang dapat dikonsumsi adalah tidak ditemukannya Coliform dan Escherichia coli dalam $100 \mathrm{ml}$ air. Penentuan kualitas air minum secara mikrobiologi menggunakan Most Probable Number Test / jumlah perkiraan terdekat. ${ }^{3}$

Depot air minum adalah industri yang melakukan proses pengolahan air baku menjadi air minum dan menjual langsung kepada pembeli. Sejak tahun 2002, mulai bermunculan depot air minum isi ulang. Usaha ini dianggap sebagai peluang alternatif, karena usaha ini membutuhkan investasi yang sedikit namun menguntungkan, ataupun bagi konsumen karena harga air minum isi ulang ini lebih murah dibandingkan air minum dalam kemasan bermerk. ${ }^{4}$ Depot air minum adalah industri yang melakukan proses pengolahan air baku menjadi air minum dan menjual langsung kepada pembeli. Menurut Keputusan Menteri Perindustrian dan Perdagangan No.651 tahun 2004, untuk menjamin kualitas produk air minum yang dihasilkan, maka depot air minum diwajibkan untuk melakukan pengujian kualitas produk di Laboratorium Pemeriksaan Air yang ditunjuk oleh Pemerintah Kabupaten/ Kota atau yang terakreditasi, dilakukan sekurang-kurangnya dalam 6 (enam) bulan sekali. $^{5}$
Kualitas air minum yang menurun secara mikrobiologi merupakan salah satu penyebab timbulnya diare. Berdasarkan profil kesehatan Kota Padang tahun 2012, tercatat kelurahan Lubuk Buaya adalah kelurahan dengan kasus diare tertinggi di Kota Padang. Terdapat 12 depot air minum isi ulang di Kelurahan Lubuk Buaya berdasarkan data dari Dinas Kesehatan Kota Padang dan tidak satupun yang melakukan pengujian produk air tahun 2013 . $^{6}$

Penelitian ini dilakukan dengan tujuan untuk mengetahui kualitas air minum yang di produksi depot air minum isi ulang di Kelurahan Lubuk Buaya Padang berdasarkan persyaratan mikrobiologis yang telah ditetapkan oleh Peraturan Menteri Kesehatan No. 492 Tahun 2010 tentang persyaratan kualitas air minum dengan mengidentifikasi keberadaan bakteri Escherichia coli pada air minum isi ulang yang diproduksi depot air minum isi ulang di Kelurahan Lubuk Buaya Padang.

\section{METODE}

Penelitian ini bersifat deskriptif yang dilakukan di Laboratorium Mikrobiologi Fakultas Kedokteran Universitas Andalas Padang dari Februari 2014 sampai Oktober 2014. Sampel pada penelitian ini adalah air minum dari seluruh depot air minum isi ulang di Kelurahan Lubuk Buaya sebanyak dua belas depot. Observasi lokasi depot air minum isi ulang dan pengambilan sampel air dilakukan di Kelurahan Lubuk Buaya Padang. Air yang menjadi sampel adalah air yang sudah menjalani proses produksi sampai dimasukkan ke dalam galon air dan diberi tutup. Pemeriksaan bakteriologi terhadap sampel air dilakukan di Laboratorium Mikrobiologi Fakultas Kedokteran Universitas Andalas. Pada pemerikaan mikrobiologi digunakan MPN indeks untuk menghitung total Coliform dalam $100 \mathrm{ml}$ air dan dilakukan empat tahap pemeriksaan yaitu: presumptive test menggunakan medium lactose broth, confirmative test menggunakan medium Brilliant green lactose broth, complete test menggunakan medium endo agar dan identification test menggunakan media triple sugar iron agar (TSIA), simmon sitrat dan semi solid. 
HASIL

Tabel 1. Hasil tes presumtif

\begin{tabular}{|c|c|c|c|c|}
\hline No & $10 \mathrm{cc}$ & $1 \mathrm{cc}$ & $0,1 \mathrm{cc}$ & Keterangan \\
\hline 1 & $-\cdots$ & $-\cdots$ & $-\cdots$ & Negatif \\
\hline 2 & +++ & ++- & -- & Lanjut test konfirmatif \\
\hline 3 & -- & -- & -- & Negatif \\
\hline 4 & -- & -- & -- & Negatif \\
\hline 5 & +++ & -+- & --+ & Lanjut test konfirmatif \\
\hline 6 & -- & -- & $-\cdots$ & Negatif \\
\hline 7 & -- & -- & $-\cdots$ & Negatif \\
\hline 8 & -- & --- & $-\cdots$ & Negatif \\
\hline 9 & ++- & -- & -- & Lanjut test konfirmatif \\
\hline 10 & ++- & ++- & --+ & Lanjut test konfirmatif \\
\hline 11 & -- & $-\cdots$ & -- & Negatif \\
\hline 12 & --- & --- & --- & Negatif \\
\hline
\end{tabular}

Keterangan: $+=$ terdapat produksi gas.

- = tidak terdapat produksi gas

Berdasarkan Tabel 1 didapatkan bahwa jumlah tabung positif pada tes presumtif sebanyak 17 tabung (15\%) dari 108 tabung reaksi yang digunakan. Dari hasil tersebut didapatkan 4 dari 12 sampel air minum $(33,3 \%)$ menunjukkan hasil positif pada tes presumtif. Sampel dengan nomor 2, 5, 9, dan 10 dilanjutkan ke tes konfirmatif.

Tabel 2. Tabel hasil tes konfirmatif

\begin{tabular}{ccccc}
\hline $\begin{array}{c}\text { No. } \\
\text { sampel }\end{array}$ & 10cc & 1cc & 0,1cc & $\begin{array}{c}\text { Total } \\
\text { bakteri } \\
\text { coliform }\end{array}$ \\
\hline 2 & +++ & ++- & --- & 93 \\
5 & +++ & --- & --- & 23 \\
9 & ++- & --- & --- & 9,2 \\
10 & ++- & ++- & --+ & 28
\end{tabular}

Keterangan: $+=$ terdapat produksi gas.

- = tidak terdapat produksi gas

Produksi gas pada tabung reaksi menunjukkan adanya pertumbuhan koloni bakteri Coliform pada medium yang digunakan, sehingga hasil positif pada tes konfirmatif dapat dimasukkan ke dalam tabel MPN Indeks untuk mendapatkan total bakteri Coliform yang terkandung dalam $100 \mathrm{ml}$ air. $^{7}$

Hasil positif pada tes konfirmatif ditanamkan ke dalam endo agar dengan cara digoreskan menggunakan jarum ose $4 \mathrm{~mm}$. Setelah diinkubasi pada suhu $36^{\circ} \mathrm{C}$ selama 24 jam, dapat dilihat pertumbuhan koloni kuman di permukaan agar.
Tabel 3. Hasil tes lengkap

\begin{tabular}{ccc}
\hline No. & $\begin{array}{c}\text { Nomor } \\
\text { Sampel }\end{array}$ & $\begin{array}{c}\text { Koloni ungu tua dengan kemilau } \\
\text { tembaga metalik dan pusat gelap }\end{array}$ \\
\hline 1 & 2 & Tidak ditemukan \\
2 & 5 & Ditemukan \\
3 & 9 & Tidak ditemukan \\
4 & 10 & Tidak ditemukan \\
\hline
\end{tabular}

Tabel 3 menunjukkan satu dari empat sampel mengandung bakteri Coliform, sedangkan tiga sampel lainnya menunjukkan pertumbuhan koloni bakteri merah muda dan tidak menghasilkan warna metalik. Untuk memastikan jenis bakteri, maka keempat sampel ini dilanjutkan ke tes identifikasi dengan reaksi biokimia.

Tabel 4. Hasil tes identifikasi

\begin{tabular}{|c|c|c|c|c|c|c|}
\hline \multirow{2}{*}{ No. } & \multicolumn{4}{|c|}{ TSIA } & \multirow{2}{*}{$\begin{array}{c}\text { Simmon } \\
\text { citrate }\end{array}$} & \multirow{2}{*}{$\begin{array}{l}\text { Semi } \\
\text { solid }\end{array}$} \\
\hline & Slant & Butt & Gas & $\mathrm{H}_{2} \mathrm{~S}$ & & \\
\hline 2 & $\mathrm{~K}$ & $\mathrm{~K}$ & - & - & + & + \\
\hline 5 & A & A & + & - & - & + \\
\hline 9 & A & A & + & - & + & + \\
\hline 10 & $\mathrm{~K}$ & $\mathrm{~K}$ & - & - & + & + \\
\hline
\end{tabular}

Keterangan; $\mathrm{A}=$ acid, $\mathrm{K}=$ alkaline, + = positif, - =negatif

Hasil tes identifikasi dengan reaksi biokimia, didapatkan sampel nomor 2 dan 10 mengandung bakteri Pseudomonas sp, sampel nomor 9 mengandung bakteri Enterobacter $s p$, dan sampel nomor 5 mengandung bakteri Escherichia coli. ${ }^{8-10}$

\section{PEMBAHASAN}

Empat dari dua belas sampel $(33,3 \%)$ tidak memenuhi persyaratan yang telah ditetapkan berdasarkan Peraturan Menteri Kesehatan No.492 tahun 2010. ${ }^{3}$ Dua belas sampel yang positif mengandung Coliform, terdapat satu sampel $(8,3 \%)$ yang mengandung bakteri Escherichia coli, sementara tiga sampel lain mengandung bakteri Coliform lain.

Adanya hasil yang positif yaitu gas di dalam tabung pada tes konfirmatif, dapat disimpulkan bahwa air sampel tersebut mengandung Coliform. Hasil tes konfirmatif ini dapat digunakan untuk menghitung jumlah perkiraan terdekat bakteri Coliform dalam air. Coliform adalah sekumpulan golongan bakteri yang dijadikan indikator untuk kualitas air dan makanan. Bakteri ini dapat ditemukan di alam seperti di tanah 
dan air. Salah satu bakteri Coliform yang menjadi indikator pencemaran feses pada air adalah Escherichia coli. Kehadiran bakteri Escherichia coli dan Coliform dalam air mengindikasikan air sudah tercemar. ${ }^{11} \mathrm{Hal}$ ini juga mengindikasikan buruknya kualitas mutu produk air minum isi ulang yang diproduksi depot air minum. Bakteri Pseudomonas aerugenosa dan Enterobacter sp yang ditemukan kemungkinan disebabkan oleh kontaminasi oleh debu, tanah dan air bilasan wadah. Bakteri ini banyak tersebar luas sehingga sangat mudah mengontaminasi air, baik pada air baku langsung maupun selama proses produksi. ${ }^{12}$

Beberapa faktor yang dapat mempengaruhi kualitas produk air minum yang dihasilkan adalah air baku, penanganan terhadap wadah, kebersihan operator dan kondisi depot. Semua depot air minum di Kelurahan Lubuk Buaya menggunakan air baku yang berasal dari Gunung Talang, Solok. Namun hasil yang didapatkan pada pemeriksaan menunjukkan 33,3\% depot dengan sampel air minum yang positif Coliform dansatu dari dua belas depot yang mengandung Escherichia coli. Salah satu bentuk menjaga kebersihan diri operator dalam menangani wadah adalah dengan mencuci tangan sebelum menangani wadah yang dibawa konsumen, gunanya untuk mengurangi kemungkinan terjadinya kontaminasi, namun tidak satupun dari dua belas operator pada depot air minum isi ulang yang dijadikan sampel yang melakukannya. Penanganan yang baik dilakukan dengan pencucian menggunakan deterjen khusus untuk bahan tara pangan dan air bersih dengan suhu sekitar $60-80^{\circ} \mathrm{C}$, lalu dibilas dengan air produk secukupnya untuk menghilangkan sisa deterjen yang digunakan untuk mencuci wadah. ${ }^{2}$ Semua depot yang menjadi sampel di Kelurahan Lubuk Buaya tidak melakukan penanganan terhadap wadah yang dibawa pembeli sesuai dengan peraturan tersebut. Cara yang umum digunakan kebanyakan depot sekarang adalah menyikat dan membilas dengan air produk, setelah itu langsung diisi dengan air produk.

Pengawasan terhadap penyelenggaraan usaha depot air minum harus tetap ditingkatkan mengingat banyaknya depot yang tidak memeriksakan mutu produk secara berkala sesuai Keputusan Menteri Perindustrian dan Perdagangan No.651 tahun 2004 . $^{5}$

\section{KESIMPULAN}

Berdasarkan penelitian yang telah dilakukan dapat disimpulkan bahwa 33,3\% sampel air minum isi ulang yang diproduksi depot air minum isi ulang di Kelurahan Lubuk Buaya tidak memenuhi persyaratan yang telah ditetapkan berdasarkan Peraturan Menteri Kesehatan No.492 tahun 2010 dan ditemukan satu sampel air minum atau $8,3 \%$ mengandung bakteri Escherichia coli.

\section{DAFTAR PUSTAKA}

1. Radji M, Oktavia H, Suryadi H. Pemeriksaan bakteriologis air minum isi ulang di beberapa depo air minum isi ulang di daerah Lenteng Agung dan Srengseng Sawah Jakarta. Majalah IImu Kefarmasian Universitas Indonesia. 2008:102-9.

2. Simadibrata $M$, Daldiyono. Diare akut. Dalam: Sudoyo AW, Setiyohadi B, Alwi I, Setiani S, editor (penyunting).. Ilmu penyakit dalam jilid I. Edisi ke5. Jakarta: Interna Publishing; 2009. hlm..548.

3. Departemen Kesehatan RI. Peraturan Menteri Kesehatan No. 492 Tahun 2010 tentang persyaratan kualitas air minum. Jakarta; 2010.

4. Pitoyo. Dua jam anda tahu cara memastikan air yang anda minum bukan sumber penyakit. 2005 (diunduh 25 April 2014). Tersedia dari: URL: HYPERLINK http://www.pitoyo.com/ebookgratif/ Air-Minum-anda-free.pdf

5. Departemen Perindustrian dan Perdagangan RI. Keputusan Menteri Perindustrian dan Perdagangan No. 651 Tahun 2004 tentang persyaratan teknis depot air minum dan perdagangannya. Jakara; 2004.

6. Dinas Kesehatan Kota Padang. Depot air minum isi ulang di Kelurahan Lubuk Buaya. Padang; 2013.

7. Sutton S. The most probable number method and its uses in enumeration, qualification, and validation. Journal of Validation Technology. 2010;15:35-8.

8. Neogen Corporation. Motility tes agar. 2011 (diunduh 15 September 2014. Tersedia dari: URL: HYPERLINK http://www.neogen.com/Acumedia/ pdf/Prodlnfo/7247 PI.pdf

9. Neogen Corporation. Simmon citrate agar. 2011 (diunduh 15 September 2014). Tersedia dari: URL: 
HYPERLINK http://www.neogen.com/Acumedia/ pdf/Prodlnfo/7156 PI.pdf

10. Neogen Corporation. Triple iron sugar agar. 2011 (diunduh 15 September 2014). Tersedia dari: URL: HYPERLINK http://www.neogen.com/Acumedia/ pdf/Prodlnfo/7156 PI.pdf
11. Geissler K, Manafi M, Amoro I, Alonso JL Quantitative determination of total coliforms and Escherichia coli in marine water. Journal of Applied Microbiology. 2000;88(2):280-5.

12. Jawets E, Melnick J, Adelberg E. Medical microbiology (terjemahan). Edisi ke- 21. Jakarta: EGC. 2007. hlm.249. 